дальнейшего развития социализма именно эти институты с помощью школьной системы и под руководством многочисленных партийных постановлений направляли учебновоспитательный процесс в республике в духе идейного воспитания учащейся молодежи. В детях видели не только будущих строителей государства, но и всесторонне развитых реформаторов нового общества.

Таким образом, воспитательный потенциал деятельности пионерской и комсомольской организаций привлекает внимание тем, что они были существенным элементом социального окружения ребенка и подростка, охватывали практически все сферы их жизнедеятельности, посредством них реализовывалась сложная система общественных отношений личности, формировалось ее мировоззрение, сознательное отношение к явлениям общественной жизни. И пионерская, и комсомольская организации, прежде всего, выполняли функцию агентов социализации несовершеннолетнего в детском обществе, в обществе сверстников.

$$
* * *
$$

1. Анпилогова Т.Ю. Роль пионерской и комсомольской организаций в политико-идеологическом воспитании детей в интернатных учреждениях Луганщины в 1920 - 1930-е гг. / Т.Ю. Анпилогова // Наследие: журнал научных публикаций. - 2016. - № 1. - С. 3 - 12 .

2. Галимуллина Н.М. Молодежь как целевая аудитория пропагандистского воздействия в предвоенные годы / Н.М. Галимуллина // Детское и молодежное движение: история и современность: материалы междунар. науч.-практ. конф. / отв ред. В.А. Кудинов. - Кострома: КГУ им. Н.А. Некрасова, 2016. - С. 76 - 79.

3. Кудинов В.А. Исторический опыт социализации детей и молодежи в общественных объединениях / В.А. Кудинов // Детское и молодежное движение: история и современность: материалы междунар. науч.-практ. конф. / отв ред. В.А. Кудинов. - Кострома: КГУ им. Н.А. Некрасова, 2016. - С. 30 - 32.

4. Ц Центральный государственный архив общественных объединений Украины (далее - ЦГАООУ). - Ф.7. - Оп. 3. - Д. 1222. - 59 л.

5. 3. - Д. 28. -344 л.

6. Бондар А.Д. Народна освіта і педагогічна наука в Українській РСР / А.Д. Бондар. - К.: Радянська школа, 1967. $-483 \mathrm{c}$.

7. ЦГАООУ. - Ф.7. - Оп. 3. - Д. 1212. - 171 л.

8. ЦГАООУ. - Ф.7. - Оп. 6. - Д. 1860. - 209 л.

9. Гаврыш О.В. Участие комсомольской организации в преодолении детской беспризорности и безнадзорности в годы послевоенного восстановления (на материалах УССР) / О.В. Гаврыш // Детское и молодежное движение: история и современность: материалы междунар. науч.-практ. конф. / отв ред. В.А. Кудинов. Кострома: КГУ им. Н.А. Некрасова, 2016. - С. 48 - 51.

10. Структура пионерской организации // Вожатый. - 1946. - № 8-9. - С. 19 - 21 .

11. ЦГАООУ. - Ф.7. - Оп. 3. - Д. 1244. - 123 л.

12. Юный ленинец. - 1951. - 29 ноября.

13. ЦГАООУ. - Ф.7. - ОП. 6. - Д. 1811. - 258 л.

14. ЛКСМ України в рішеннях з’їздів та коференцій. 1919 - 1966 / редкол. О.С. Капто, Ю.В. Бабко та ін. - К.: Молодь, 1969. - 667 с.

15. Государственный архив Донецкой Народной Республики. - Ф. 2852. - Оп.1. - Д. 368. - 107 л.

16. ЦГАООУ. - Ф.7. - ОП. 3. - Д. 1444. - 309 л.

17. ЦГАООУ. - Ф.7. - Оп. 2. - Д. 1218. -50 л.

\title{
Жегульская Т.Ю. \\ Создание сельских народных библиотек в России в пореформенный период
}

Воронежский государственный педагогический университет (Россия, Воронеж)

doi: 10.18411/trnio-09-2021-34

\section{Аннотация}

В статье определяется роль сельских народных библиотек и читален в деле внешкольного образования народа в $1860-\mathrm{x}$ - 1890-х гг., а также даётся обзор законодательства, регламентирующего их открытие и деятельность.

Ключевые слова: внешкольное образование, просвещение, грамотность, народная библиотека, читальня, цензура, каталог книг. 
Abstract

The article defines the role of rural national libraries and reading rooms in the out-of-school education of the people in the 1860s - 1890s, and also provides an overview of the legislation governing their opening and activities.

Keywords: out-of-school education, enlightenment, literacy, public library, reading room, censorship, book catalog.

Отмена крепостного права, буржуазные реформы, проведенные в России в течение 60-70-х годов XIX века, существенно ускорили становление капиталистических отношений, активизировали процессы общественного развития в целом. Технический прогресс, трансформация социальной структуры, изменения в системе управления государством предопределили необходимость совершенствования прежде всего системы образования.

В условиях особой атмосферы предреформенных лет в России возникло и сложилось движение интеллигенции, выступившей за повышение культурного уровня жизни народа, всеобщую грамотность.

Термин «внешкольное образование» появился в отечественной истории педагогики во 2-й половине XIX века для обозначения культурно-просветительской деятельности, направленной на удовлетворение образовательных запросов населения (главным образом, взрослого). Учреждения внешкольного образования: воскресные и вечерние школы, повторительные классы, народные чтения, народные библиотеки и читальни, книжные склады, народные университеты, народные дома, народные театры и пр. - создавались на общественные и частные средства и не входили в государственную систему народного образования. Внешкольное образование поддерживали видные педагоги и общественные деятели того времени - Н.И. Пирогов, К.Д. Ушинский, Н.А. Корф, В.И. Водовозов и др.

Важную роль в деле внешкольного образования играли народные (бесплатные) библиотеки и читальни. Развитие их шло в 60-80-е годы XIX века параллельно с другими видами просветительной работы. Сознавая, что для эффективности распространения знаний в народе нельзя довольствоваться лишь наличием сети пришкольных и публичных библиотек, действовавших главным образом в губернских центрах и недоступных для трудящихся из-за значительной платы за чтение, передовые деятели внешкольного образования в начале 1870-х годов подняли вопрос об открытии народных библиотек и о допущении грамотных крестьян к пользованию библиотеками сельских начальных училищ.

Даже заканчивая школу, крестьянские дети не могли применять свои знания за неимением книг или читали такие книги, которые ничего не могли дать ни в умственном, ни в нравственном отношении. Возникал так называемый «рецидив безграмотности», когда основная часть детей из бедных семей после освоения грамоты, получив самые элементарные знания, не могла закрепить их в своей повседневной жизни, так как крестьяне крайне редко выписывали газеты и покупали книги, зачастую просто не имея средств и времени для чтения. Так, В.П. Вахтеров в своей работе «Внешкольное образование народа» писал: «Отсутствие библиотек при сельских училищах является одной из причин того, что полученные в школе знания вскоре исчезают. Поэтому нужно как можно более развивать систему сельских библиотек» [2, с. 10].

К подобным выводам пришёл и депутат от духовенства священник Крепкогорский, который на страницах журнала «Русская школа» отмечал: «Нужно шире поставить дело народных библиотек. Необходимость эта обусловливается тем, что окончившие курс сельской школы не имели впоследствии общения с нею, не имели под руками книг, забывали грамоту, и расходы земств на их обучение пропадают почти даром» [7, с. 222].

Такое положение наблюдалось во многих губерниях России. По результатам исследований земских статистов в 1880-1890-х годах было установлено, что уже через 3-4 года после окончания начальной школы «рецидив безграмотности» имел место у значительной части крестьянского населения [6, с. 138]. 
Видный деятель народного образования Н.А. Корф, анализируя положение с грамотностью в 80-е годы XIX века, пришёл к выводу, что 8,3\% окончивших школу разучились читать или читают, не понимая прочитанного, 7,1\% не могли подписаться, 15,2\% забыли два первых действия арифметики [4, с. 30].

Поэтому создание народных библиотек являлось одним из важных направлений повышения грамотности сельского населения и борьбы с рецидивом безграмотности.

Длительное время деятельность сельских публичных библиотек не была законодательно регламентирована. В 60-х годах XIX века в законодательстве вообще отсутствовало само понятие «библиотека», подобные учреждения для народа именовались «кабинетами для чтения». Основными законодательными актами, не утратившими своей силы и в 90-е годы XIX века, являлись некоторые статьи Устава о цензуре и печати, изданного в 1865 году. Они касались литографии, книжных магазинов, лавок и «кабинетов для чтения». Статьи 158 и 175 данного Устава определяли порядок открытия: каждый кабинет для чтения мог учреждаться с разрешения губернатора. Он же мог отклонить любое ходатайство без всяких мотивов, не связан был сроками их рассмотрения и разрешения. Не оговаривались и условия учреждения библиотек в сёлах, так что для крестьянского населения подобные учреждения вообще были недоступны.

В 1867-68 годах Министерством народного просвещения был принят целый ряд циркуляров, дополняющих и разъясняющих вышеназванный Устав. Эти попытки правительства примирить несовершенный закон с запросами жизни привели к дальнейшему усложнению порядка открытия библиотек и надзора за ними.

Так, в 1884 году в качестве временной меры были установлены правила, вошедшие затем в Свод законов в качестве примечания к статье 175 цензурного Устава [3, с. 10]. Желающие открыть библиотеку или кабинет для чтения в своём ходатайстве должны были указать, кто будет являться ответственным лицом. Министру внутренних дел предоставлялось право закрывать публичные библиотеки и общественные читальни в случае необходимости, определять издания, которые не могут быть допущены в библиотеки. Фактически данные правила давали министру право запрещать библиотекарям иметь у себя и выдавать подписчикам даже те книги, которые были разрешены цензурой и продавались на книжном рынке. Таким образом, законодательство полностью передавало ведение публичных библиотек Министерству внутренних дел. Министерство народного просвещения было отстранено от прямого влияния на эту деятельность. Только в отдельные библиотечные комитеты вводились в качестве непременных членов представители учебного ведомства (директора училищ или штатные смотрители). Отстранение Министерства народного просвещения было шагом весьма логичным, так как весь надзор за цензурой и библиотеками был передан в руки Министерства внутренних дел. Однако по докладу министра народного просвещения от 4 февраля 1888 года на Ученый комитет этого ведомства была возложена обязанность пересмотра каталогов книг народных библиотек. Таким образом, к надзору одного министерства присоединился специальный надзор другого. Но ни одно из них реально не прилагало никаких усилий к распространению библиотек в селах. Лучшим примером того может служить деятельность Ученого комитета Министерства народного просвещения, который вместо возложенного на него пересмотра каталогов книг народных библиотек стал составлять, печатать и издавать списки книг, наиболее пригодных, по его мнению, в библиотеках-читальнях, которые вскоре стали обязательными.

Произведя замену одного поручения другим, Учёный комитет достиг упрощения своей работы, но при этом в народные библиотеки был закрыт доступ большому количеству литературы, ранее допущенной общей цензурой. В результате, в народные библиотеки могло проникать не более $1 / 10$ части того, что издавалось в России, что ограничивало права читателей.

Специальный ограничительный каталог книг, допущенных в бесплатные библиотекичитальни, включал 3,8 тысяч названий, качественное содержание которых не вполне соответствовало потребностям крестьянского населения, а подчас было совершенно недоступно для понимания. 
Более того, с 1884 года существовал Алфавитный указатель произведений печати, запрещённых в публичных библиотеках и общественных читальнях [5, с. 271], который включал все собрания сочинений или отдельные издания Герцена, Добролюбова, Писарева, Нефёдова, Мордвинцева, Слепцова, Короленко, Лаврова, Л.Н. Толстого и многих других. Под запрет попали и такие журналы, как «Современник», «Отечественные записки», «Дело», «Русская мысль», «Русское слово», «Устои» и другие.

В целом же крестьянству запрещалось читать все то, что в своё время составляло душу передовой литературы и публицистики. Установленный для народных библиотек каталог постоянно подвергался критике и со стороны земских учреждений, и отдельных представителей интеллигенция, а также и крестьян. Несмотря ни на что, в 70-80-х годах в ряде местностей страны появляются народные библиотеки, открытые на средства земств, волостных и сельских обществ, просветительских и благотворительных организаций, частных лиц. Существенный вклад в развитие сети читален внесли Петербургский и Московский комитеты грамотности. За период с 1861 по 1895 год Петербургским комитетом грамотности было направлено в сельскую местность, главным образом для комплектования народных библиотек и читален, 1200 тысяч книг [9, с. 133]. Около 230 сельских библиотек за эти же годы было открыто при содействии Московского комитета грамотности.

Встревоженное ростом народных библиотек и читален, правительство 15 мая 1890 года приняло специальные Правила о бесплатных народных читальнях и о порядке надзора за ними, в которых в дополнение к общему законодательству для публичных библиотек регламентировалась деятельность народных библиотек и читален. Согласно Правилам, народные библиотеки и читальни могли открываться лишь со специального разрешения губернаторов, которым предоставлялось также право по своему усмотрению закрывать народные библиотеки и читальни вследствие малейших отклонений от установленных норм. Если ранее в народные библиотеки и читальни могли поступать все книги, одобренные цензурой, то Правила 1890 года ограничивали их фонды книгами и повременными изданиями, специально отобранными для них Ученым комитетом Министерства народного просвещения [8, с. 7].

Введение министерских каталогов сильно ограничивало просветительное значение народных библиотек и читален, наносило существенный вред делу внешкольного образования. Общее число названий книг, разрешенных для народных библиотек и читален (не считая изданий духовного ведомства), к середине 1890-х годов приближалось к 3 тысячам, что составляло лишь $3,3 \%$ всех изданных на русском языке книг [1, с. 131].

Кроме того, получив по Правилам 1890 года довольно широкие полномочия, губернаторы своей властью могли и разрешить, и запретить устройство библиотек-читален, затянуть рассмотрение ходатайств по данному вопросу закрыть уже существующую народную библиотеку по тем или иным причинам. Нередко в лице губернатора сельские общества встречали препятствия для создания народных библиотек в селениях.

Не только сложности с порядком разрешения на открытие библиотек тормозили широкое распространение этих просветительских учреждений. Не менее пагубно отражались на их деятельности и проблемы с их заведованием, надзором за ними и порядком разрешения книг, допускаемых в библиотеки. В итоге частым явлением в деятельности библиотекчитален стало значительное сокращение их в первые же годы после открытия.

Однако при всей сложности устройства бесплатных народных библиотек и читален в селах в конце XIX века отмечался их количественный рост. Ни экономические трудности крестьянской жизни, ни финансовая ограниченность земств и иных просветительских обществ, а также несовершенство законодательства не могли приостановить процесс «окультуривания» крестьянства посредством книги.

$$
\text { *** }
$$

1. Абрамов, К.И. История библиотечного дела в СССР: учебник для библ. фак. ин-тов культуры, пед. вузов и ун-тов / К.И. Абрамов. - 3-е изд., перераб. и доп. - М.: Книга, 1980. - 352 с.

2. Вахтеров, В.П. Внешкольное образование народа / В.П. Вахтеров. - М.: Тип. т-ва И.Д. Сытина, 1896. - 380 с. 
3. Звягинцев, Е.А. Правовое положение народных библиотек за 50 лет / Е.А. Звягинцев. - М.: Кн. склад «Для самообразования, б-ки и школы» Е.Д. Трауцкой, 1916. - 56 с.

4. Корф, Н.А. Образовательный уровень взрослых грамотных крестьян / К.Л. Корф // Русская мысль. - 1881. Кн. 10.

5. Лейкина-Свирская, В.Р. Интеллигенция в России во второй половине XIX века / В.Р. Лейкина-Свирская. М.: Мысль, 1971. - 366 с.

6. Миронов, Б.Н. Грамотность в России 1797-1917 годов / Б.Н. Миронов // История СССР. - 1985. - № 4. - С. 137-153.

7. Русская школа. - 1895. - № 12.

8. Указания к устройству читален. Узаконения о бесплатных народных библиотеках (читальнях). Примерные их уставы, составленные С-Петербургским Комитетом грамотности. Примерный список книг для бесплатных народных библиотек и читален, допускаемых в них правилами 15 мая 1890 г. - 3-е изд., доп. СПб, 1895.

9. Чехов, Н.В. Народное образование в России с 60-х годов ХІХ века / Н.В. Чехов. - М.: Польза, $1912 .-224$ с.

\section{Касарова В.Г. \\ Уроки истории. Монография Г.Г. Касарова «Стачечное движение в России в годы Первой мировой войны. Июль 1914 г. - февраль 1917 г.: Хроника»}

(Россия, Москва)

doi: 10.18411/trnio-09-2021-35

\section{Аннотация}

Автор статьи дает обзор серьезного научного труда, посвященного стачечному движению в России в голы Первой мировой войны с июля 1914 по февраль 1917 годы. Этот серьезный научный труд показывает историческую хронику событий. Хроника создавалась известным историком, исследователем стачечного движения в России Касаровым Георгием Георгиевичем. Хроника всегда будет интересна историкам, потому что она дает возможность для более глубокого и полного освещения событий. Серьезные архивные данные и документы были представлены в фундаментальном труде исследователя. Автор статьи видит уникальность данной монографии для исторической науки и ее развития, поскольку она помогает понять причины роста стачечного движения в различных частях России, что привело к смене политического строя. В статье подчеркивается серьезный вклад в развитие исторической науки, сделанный Г.Г. Касаровым.

Ключевые слова: научный труд, хроника, Г.Г. Касаров, стачечное движение, Россия, исследование, архивные документы, историческая наука, уникальность, монография.

\section{Abstract}

The author of the article gives an overview of serious scientific work dedicated to the strike movement in Russia in the goals of the First World War from July 1914 to February 1917. This serious scientific work shows the historical chronicle of events. The chronicle was created by a famous historian, a researcher of the strike movement in Russia, Kasamar George Georgievich. The chronicle will always be interested in historians, because it makes it possible for a deeper and complete lighting of events. Serious archival data and documents were presented in the fundamental work of the researcher. The author of the article sees the uniqueness of this monograph for the historical science and its development, since it helps to understand the reasons for the growth of the strike movement in various parts of Russia, which led to a change in political system. The article emphasizes a serious contribution to the development of historical science, made by G.G. Casarov.

Keywords: scientific work, chronicle, G.G. Kasarov, strike movement, Russia, research, archival documents, historical science, uniqueness, monograph.

Георгий Георгиевич Касаров - доктор исторических наук, профессор, заслуженный деятель науки Российской Федерации, академик Академии военных наук, академик Российской академии естественный наук, член-корреспондент Петровской академии науки и 